\title{
Estimation of Self-Neutralisation Rates in a Lignite Pit Lake
}

\author{
Joscha Opitz ${ }^{1,2}$ (1) $\cdot$ Matthias Alte ${ }^{1} \cdot$ Martin Bauer ${ }^{1} \cdot$ Wolfgang Schäfer $^{3} \cdot$ Thomas Söll $^{4}$
}

Received: 15 June 2019 / Accepted: 11 May 2020 / Published online: 25 May 2020

(c) The Author(s) 2020

\begin{abstract}
Natural anaerobic biogeochemical processes used for passive treatment of AMD were observed in the extensive shallow water zone of a polymictic pit lake in the former German lignite district of Upper Palatinate. Although continuously fed by acidic metalliferous groundwater, lake-pH increased from 3.5 to circumneutral over a little more than 10 years. The natural attenuation processes were studied and quantified using a regional surface- and groundwater flow model linked with hydrochemical monitoring datasets to establish a simple mass balance. The acidity inflow was estimated at $\approx 5900 \mathrm{kmol}$ over the period 2014-2018, which corresponds to an average inflow of $\approx 1190 \mathrm{kmol} / \mathrm{a}$. This estimate is in very good accordance with an acidity inflow rate for the period 2000-2014 estimated from acidity deposition in the sediment based on sediment core analyses plus the calculated cumulative acidity outflow based on extrapolation of pre-neutralisation acidity levels in the pit lake, together yielding a total acidity of $\approx 15,000 \mathrm{kmol}$, which corresponds to an inflow rate of $\approx 960 \mathrm{kmol} / \mathrm{a}$. The results strongly indicate that the pit lake self-neutralised due to beneficial environmental and ecological conditions, amplified and potentially initialised by the circumneutral discharge from a chemical mine water treatment plant, and that well-known biogeochemical mechanisms such as natural microbial sulfate reduction were the driving force. The results give rise to perspectives concerning the potential development of pit lakes if ecological considerations are considered.
\end{abstract}

Keywords Sulphate reduction $\cdot$ Mass balance $\cdot$ SRB $\cdot$ Lake sediment $\cdot$ AMD

\section{Introduction}

Mining activities, especially open-pit coal and lignite mining, are often associated with the extensive formation of acid mine drainage (AMD). Diffuse AMD is predominantly generated by contact of sulphide-bearing minerals with oxygen and water below the surface upon lowering of the groundwater level during mining activities. The resulting

Electronic supplementary material The online version of this article (https://doi.org/10.1007/s10230-020-00692-9) contains supplementary material, which is available to authorized users.

Joscha Opitz

joscha.opitz@base-technologies.com

1 Base Technologies GmbH, Josef-Felder-Straße 53, 81241 Munich, Germany

2 Department of Hydrology, University of Bayreuth, Bayreuth, Germany

3 Steinbeis Transfer Center for Groundwater Modelling, Wiesloch, Germany

4 Büro für Geohydraulische Modellrechnungen, Schwäbisch Gmünd, Germany acidic and metalliferous groundwater can cause extensive pollution and environmental impairment downstream of the actual pollution source. Although there is still a great knowledge gap, studies by Mayes et al. (2008) indicate that diffuse contamination can account for as much as $50 \%$ up to nearly $100 \%$ of surface water pollution and metal influx, depending on mine and catchment characteristics. Whereas point source AMD can easily be collected and treated, the effective control and treatment of diffuse AMD is considered to be almost impossible. Consequently, diffuse AMD is often the main cause for both surface- and groundwater pollution.

Pit lakes are a common means of compensating for the deficit of backfill material in extensive open pit mining districts. Due to mining-induced processes in the post-mining landscape, pit lakes are often acidic and display elevated concentrations of mining-typical metals (Peine 1998; Schultze et al. 2010; Totsche et al. 2003). Neutralisation of pit lakes is usually the first step in pollution control, since solubility and mobility of hydrolysable metals $(\mathrm{Fe}, \mathrm{Al}, \mathrm{Mn})$ as well as other contaminants closely associated with the former in post-mining waters are predominantly $\mathrm{pH}$-dependent (Lee et al. 2002; Zänker et al. 2003). 
It is well known that natural biogeochemical processes such as microbially mediated sulphate and iron reduction can lead to de-acidification and metal immobilisation (Geller et al. 2009; Koschorreck and Tittel 2007). Microbial sulphate reduction was observed to contribute to the overall water quality of natural wetlands and small pit lakes (Tuttle et al. 1969) and is used in passive treatment systems such as anaerobic wetlands and successive alkalinity producing systems (SAPS) (Skousen et al. 2017). Sulphate reducing bacteria (SRB) require anoxic conditions, the absence of ferric iron, a sulphate concentration $>100 \mathrm{mg} / \mathrm{L}$, and a carbon source, and thrive at circumneutral pH (Burns et al. 2012):

$$
\begin{gathered}
4 \mathrm{FeOOH}+16 \mathrm{H}^{+}+8 \mathrm{SO}_{4}^{2-}+15 \mathrm{CH}_{2} \mathrm{O} \\
\rightarrow 4 \mathrm{FeS}_{2}+25 \mathrm{H}_{2} \mathrm{O}+15 \mathrm{CO}_{2}
\end{gathered}
$$

Various measures have been tried and investigated to actively improve water quality of acidic pit lakes (e.g. Dowling et al. 2004; Fisher and Lawrence 2006; Fyson et al. 1998; Rönicke et al. 2010), and the lake sediment was identified as a stable and spacious long-term sink for mine water contaminants (Junge and Schultze 2016). In this context, both dissimilatory microbial sulphate reduction and discharge of neutral or net-alkaline (river) water have been investigated in terms of their potential as a tool to manage water quality in acidic pit lakes (e.g. Delgado-Martin et al. 2013; Fyson et al. 2006; Geller et al. 2009; Juncosa et al. 2019; Schultze et al. 2005, 2009), yet no stable and self-sustaining system based solely on sulphate reduction has been discovered or created so far. Various laboratory experiments and field-scale studies, especially in the lignite fields of eastern Germany, have tried to determine and/or reproduce the environmental conditions necessary for natural in-lake neutralisation. Respective laboratory batch or column studies were successful in establishing and maintaining intensive dissimilatory sulphate reduction in an organic substrate, concomitantly increasing $\mathrm{pH}$ in the supernatant water column (e.g. Becerra et al. 2009; Castro et al. 1999; Frömmichen et al. 2003, 2004; Fyson et al. 2006; Lund et al. 2017). Although a similar environment was artificially created in field trials by addition of external substrates, both the resultant sulphate reduction and $\mathrm{pH}$ increase were only temporal (e.g. Geller et al. 2009; Koschorreck et al. 2007, 2011; Lewis et al. 2003; Lund et al. 2017; McCullough et al. 2008), with system instability attributed to reoxidation of reduced sulphur species as a consequence of an inevitable exchange at the interface between sediment/substrate and the water column (e.g. Geller et al. 2009; Koschorreck and Tittel 2007; Peiffer 2016; Peine et al. 2000).

Sulphate reduction rates determined in various acidic pit lakes were, therefore, concluded to be insufficient for selfneutralisation and it was assumed that natural neutralisation is only possible in mildly acidic pit lakes with relatively low acidity inflow, long retention time, and/or secondary alkalinity sources (Peiffer 2016; Salmon et al. 2008). Although the potential of sulphate reduction for natural in-lake neutralisation is widely acknowledged in principle (e.g. Castro and Moore 2000; Klapper and Geller 2001; Koschorreck and Tittel 2007; Tuttle et al. 1969; Wendt-Potthoff et al. 2012), respective field trials have not yet met expectations. To date, there is no report of a full-scale pit lake self-neutralising predominantly by natural biogeochemical processes. Here, we describe a formerly acidic pit lake that self-neutralised over the course of 10-15 years. Investigations were conducted to fathom the reason, sink, and cause for the natural acidity removal (Opitz et al. 2017; Schäfer et al. 2016). Furthermore, the study briefly addresses practical implications regarding the setup of the sediment-water-interface of pit lakes regarding AMD-mitigating processes.

\section{Background and Site Description}

Lake Knappensee is a pit lake in the former lignite mining district of Upper Palatinate in southeast Germany (small location map in Fig. 1). Most of the formerly $50 \mathrm{~m}$ deep pit was backfilled, resulting in an unusually shallow pit lake with a surface area of $\approx 550,000 \mathrm{~m}^{2}$ and a water volume of $1.2 \times 10^{6} \mathrm{~m}^{3}$. Flooding of the artificial lake started in 1981 and ended in 1982. Lake Knappensee (hence simply referred to as Knappensee) is the upstream link in a cascade of two pit lakes with much of the catchment area comprising mined land. Groundwater from surrounding former opencast segments and waste rock dumps discharges entirely to the two pit lakes. In 1995, a mine water treatment plant was installed in close vicinity to Knappensee for chemical treatment of seepage water from an adjacent former open pit that was subsequently used as a landfill for waste rock and lignite ashes. Chemical treatment is achieved by oxygenation, $\mathrm{pH}$ stabilisation, and flocculation for iron removal. The treated water is discharged into the pit lake at the shallow northern end (Fig. 1).

Knappensee is a polymictic pit lake (Nixdorf and Ramm 2016), with an average depth of less than $4 \mathrm{~m}$ and a maximal depth of only $9.2 \mathrm{~m}$ in the southern corner (Fig. 2). The pit lake's water level is controlled by a free spillway draining to the subsequent pit lake in the two-lake cascade. Knappensee's littoral can be visually sub-divided into riparian and aquatic strips. Relative to other areas of the lake, the littoral zone had higher biomass production, as visually determined by silting up and hydrarch succession. The northern part of Knappensee represents an extensive shallow water zone of $\approx 250,000 \mathrm{~m}^{2}$, with a maximal depth of $2 \mathrm{~m}$ (Fig. 2). The low water depth allows light transmission to the lake bottom and thus, most of this shallow water zone is densely vegetated by rooted, floating, and submerged bulbous rush 


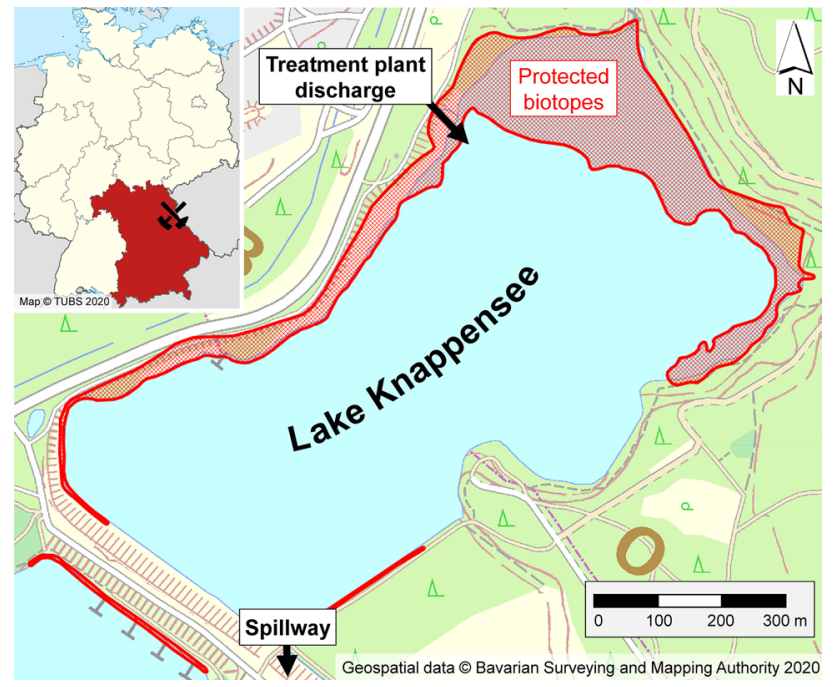

Fig. 1 Overview map and site map of Lake Knappensee

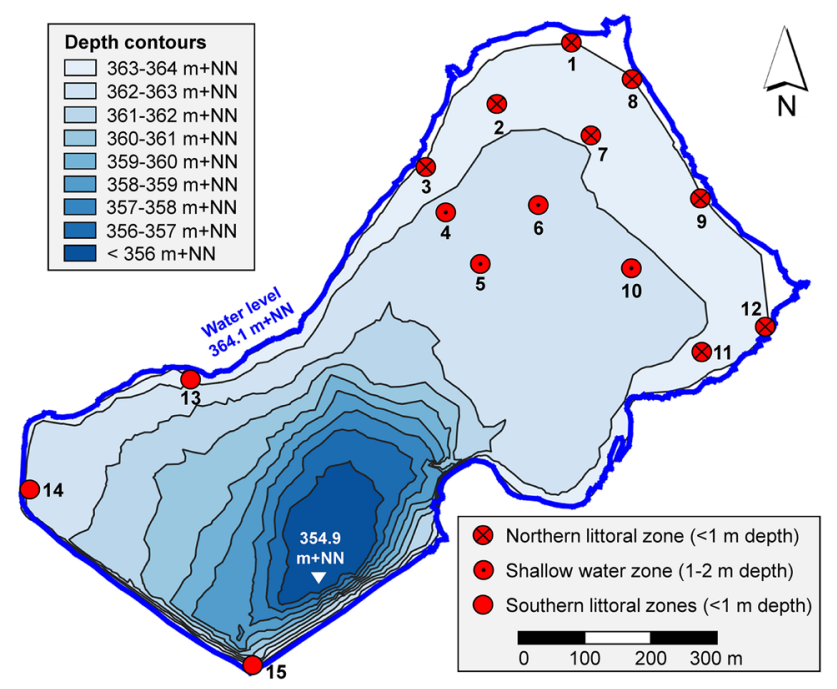

Fig. 2 Depth contours (isobaths) of Lake Knappensee and sediment core sampling locations

(Juncus bulbosus), a hydrophyte that is often a primary pioneer macrophyte for colonisation of acidic pit lakes (Chabbi 1999; Nixdorf et al. 2001). The western and northern shores are lined with aquatic and waterlogged reed and cattail belts (predominantly Phragmites australis and Typha latifolia). Although Knappensee is a relatively young pit lake, it is already regarded as a landscape lake due to its excellent ecological development. Approximately $115,000 \mathrm{~m}^{2}$ of the densely vegetated littoral zones around the pit lake are categorised as valuable hydrosere biotopes, protected by both Federal and Bavarian Nature Conservation Acts (red shading in Fig. 1) (BMU 2009; StMUV 2011).
Even accounting for the discharge of circumneutral water from the treatment plant since 1995, neutralisation of Knappensee occurred unexpectedly fast, with all other pit lakes in the former lignite district of Upper Palatinate remaining acidic to date and/or neutralising much slower (Nixdorf and Ramm 2016). Modelling of acidity fluxes to and from the pit lake over the years by way of a regional groundwater flow model coupled with acidity measurements from surrounding groundwater observation wells estimated the acidity of Knappensee to remain at $\approx 0.8 \mathrm{mmol} / \mathrm{L}$ due to extensive AMD formation in the surrounding mined land (Schäfer et al. 2016). However, the lake water showed progressively decreasing acidity, deviating from the results of the acidity transport model that had, up to that point, been in accordance with actual field conditions. With neutralisation occurring within a decade and thus much faster than groundwater flow to the pit lake from the surrounding mined land (order of several decades), this emerging "acidity deficit" was interpreted as a newly arising sink-term missing in the model that "consumed" acidity. Based on visual and organoleptic observations of reduced sulphur species in the course of sediment excavations in the anoxic substrate of Knappensee's marshy, near-shore hydrarch zones (e.g. characteristic blackish grey and dark green matrix concomitant with the strong, distinctive $\mathrm{H}_{2} \mathrm{~S}$-odor on application of weak $\mathrm{HCl}$ ) in 2011, the pit lake sediment was identified as the most likely sink for acidity as a result of intensive dissimilatory sulphate reduction. Thereupon, investigations were conducted to not only qualitatively investigate potential acidity immobilisation in the Knappensee sediment, but also make a rough (quantitative) estimate of the respective mass fluxes. The main objective was to determine if, and to what extent, natural sulphate reduction may have been the driving force of neutralisation.

\section{Methods}

Acidity transport and deposition around Knappensee was investigated from two angles:

1. Development of a simple mass balance for Knappensee for not only acidity, but also several other substances for validation purposes, by: (a) evaluation of water quality monitoring results for both surface- and groundwater inflow and outflow, (b) geochemical modelling of acidity for all water samples as a basis for estimation of acidity fluxes to and from Knappensee, and (c) application of a regional surface- and groundwater flow model for quantification of flow volumes to and from Knappensee.

2. Sampling of $2 \times 15$ sediment cores across the lake in 2013 and 2014 and analysis with a focus on reduced 
sulphur species for estimation of acidity deposition in the lake sediment.

\section{Monitoring}

Lake water was sampled at the spillway yearly from 1984 to 1991 , monthly from 1992 to 2012, and bimonthly since 2013. Discharge from the treatment plant was sampled monthly since 2011. Sampling and analysis of all groundwater observation wells in the former lignite district was conducted yearly since installation of the wells. Inflows from two small intermittent tributaries were sampled twice each in 2019 to obtain a rough estimate of the respective water chemistry. All samplings and analyses were conducted by certified commercial laboratories. Both surface water samples and groundwater pumped from wells were analysed for hydrochemical parameters $(\mathrm{pH}$, specific conductance, redox potential, dissolved oxygen, temperature) in the field using state-of-the-art field meters (currently WTW Multi 3420 IDS). Several water samples for laboratory analysis were taken, with water samples for Fe(II)and ICP-analysis, stabilised using sulphuric and nitric acid, respectively. All water samples were immediately cooled and transported to the laboratory for analysis of major cations and metals ( $\mathrm{Al}, \mathrm{As}, \mathrm{B}, \mathrm{Ba}, \mathrm{Ca}, \mathrm{Co}, \mathrm{Cr}, \mathrm{Cu}$, $\mathrm{Fe}, \mathrm{K}, \mathrm{Mg}, \mathrm{Mn}, \mathrm{Na}, \mathrm{Ni}, \mathrm{Pb}, \mathrm{V}, \mathrm{Zn}$ ) via ICP (ISO 2007), anions (Cl, F, $\mathrm{SO}_{4}, \mathrm{NO}_{3}, \mathrm{NO}_{2}, \mathrm{PO}_{4}$ ) via IC (ISO 2009) as well as $\mathrm{Ks}_{4.3}, \mathrm{~Kb}_{8.2}$, TC, TIC, and TOC (DIN 1997, 2005). Acidity was calculated for all samples based on the analytical results (pH, $\mathrm{Fe}(\mathrm{II}), \mathrm{Fe}(\mathrm{III}), \mathrm{Mn}, \mathrm{Al}, \mathrm{Zn}, \mathrm{Ca}$, $\mathrm{Mg}, \mathrm{SO}_{4}, \mathrm{Cl}, \mathrm{NH}_{4}, \mathrm{Na}, \mathrm{K}$, and $\mathrm{NO}_{3}$ considered for ionic strength) and corrected for $\mathrm{CO}_{2}$ using PHREEQC broadly following Kirby and Cravotta (2005) and Peine (1998). Alkalinity was calculated via $\mathrm{Ks}_{4.3}$ or TIC for $\mathrm{pH}$ above and below 4.3 , respectively.

Discharge volume from the treatment plant was continuously measured in high resolution by a magneto-inductive flowmeter (Endress + Hausser Promag 50). Apart from that, surface and groundwater flow to and from Knappensee were taken from the lake's hydrologic-meteorological balance in a calibrated regional surface-groundwater flow model, as schematically illustrated in Fig. 3 . The corporate model was previously developed for and applied in the course of various environmental impact assessments in the former lignite district using MODFLOW with a streamflow package, allowing quantification of subsurface hydrodynamics, direct surface runoff, and surface water flow. Since the model was developed for corporate purposes, only the basic structure and boundary conditions are provided at hand: in the vicinity of Knappensee, the model has a grid resolution of typically $10 \times 10 \mathrm{~m}$ (between $5 \times 5$ and $20 \times 20 \mathrm{~m}$ ) and broadly encompasses six layers, with Triassic sandstones as the base overlaid by Tertiary sediments that in pre-mining days hosted the lignite and nowadays are characterised by and implemented in the model as either remaining Tertiary sedimentary rocks (mainly sands, clays, and residual lignite) or post-mining waste rock dumps and flooded voids. In order to couple atmosphere-land interaction and groundwater hydrodynamics, rainwater as derived from official regional precipitation records provided by the German Meteorological Service (DWD) was divided into evapotranspiration, surface runoff, and groundwater recharge using a soil water balance model for the unsaturated zone based on surface morphology (stream catchments) and hydrotopes. Surface flow to the pit lake from other sources (small tributaries) were found to be episodic and, by comparison, small, and thus calculated from the lake's overall hydrologic water balance. Lake outflow was monitored at the spillway to double-check the water balance.

\section{Sediment Investigations}

Sampling locations for sediment cores were arranged roughly along transects, focusing on areas of the pit lake with abundant

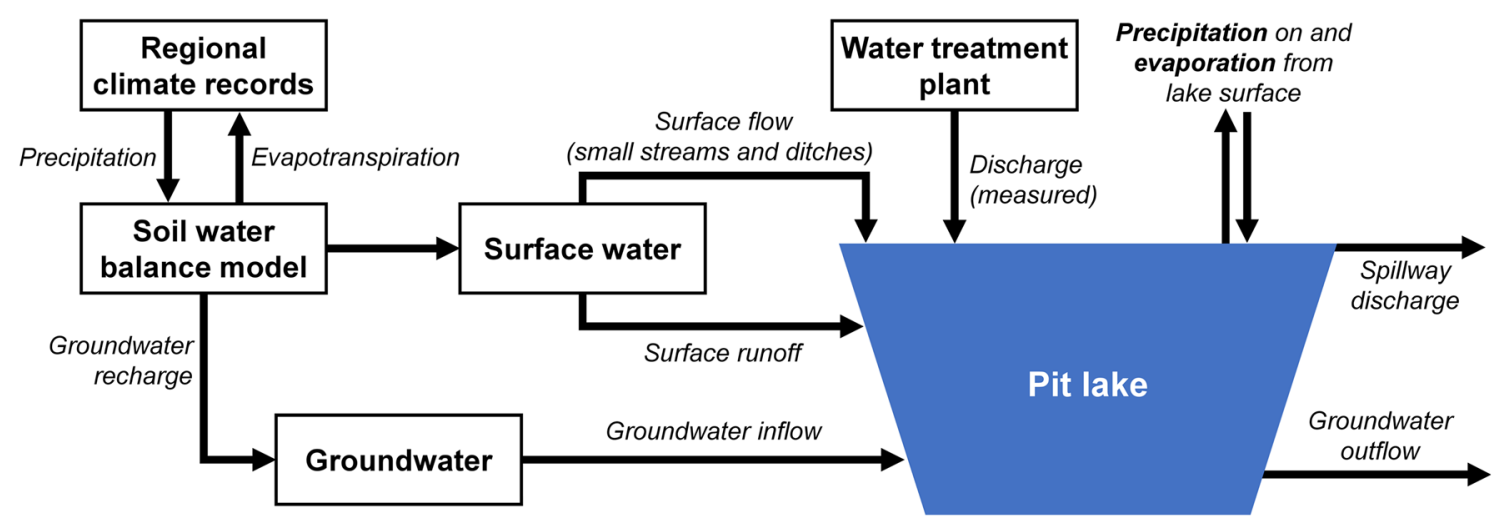

Fig. 3 Simplified schematic illustration of the regional surface- and groundwater flow model 
hygrophilous vegetation where a thick (and organic-rich) sediment was to be expected, i.e. the shallow northern half of the lake as well as the northwestern to northeastern shoreline. Sampling locations were similar for both sampling campaigns in November 2013 and December 2014 and sediment cores $(n=15$ each) were categorised according to location and water depth in the northern littoral zone $(n=8)$, shallow water zone $(n=4)$, and southern littoral zone $(n=3)$, as illustrated in Fig. 2 . We abstained from sampling sediment cores in deeper parts of the lake due to associated technical difficulties and high costs, and because sediment accumulation was expected to decrease in deeper parts of the lake. Cores were collected with a gravity corer in $1 \mathrm{~m}$ long Plexiglas liners with an internal diameter of $6 \mathrm{~cm}$. The liners were manually driven into the lake sediment until stopped by the clearly distinguishable, much harder lakebed. Sampled liners containing sediment and supernatant lake water were immediately sealed airtight with rubber plugs, visually inspected for potential disturbances, measured for sediment layer thickness and stored in coolers for transport to the laboratory within one day. Only undisturbed cores were subjected to further investigation. The 2013 sediment samples were analysed for dry substance content (weight- $\%$ ) and organic content (ISO 1996a, b) as well as elemental composition via aqua regia digestion and ICP (same cations and metals as for water samples) (ISO 1997, 2007). The 2014 sediment samples were analysed for different sulphur compounds (elemental sulphur, acid volatile sulphur, and chromium-reducible sulphur) according to the methodology described by Peine (1998) and Peine et al. (2000) to investigate acidity deposition in the Knappensee. Acid volatile sulphur (AVS) and chromium reducible sulphur (CRS) comprise monosulphides (e.g. FeS) and elemental sulphur plus disulphides $\left(\mathrm{S}^{0}\right.$ plus $\mathrm{FeS}_{2}$ ), respectively. Pyrite content $\left(\mathrm{FeS}_{2}\right)$ of the samples was calculated by the difference of CRS and elemental sulphur.

The sealed 2014 liners were stored in a cold room at $4{ }^{\circ} \mathrm{C}$ until opened and dissected under constant nitrogen flux. At least three to four composite samples (plus some replicas) were taken across each core, excluding the underlying lakebed matrix and the overlying (fresh) detritus. The samples were immediately introduced to a laboratory glove box and further analysed under strictly anoxic nitrogen atmosphere at 5.0 level of purity. Elemental sulphur was determined by way of cyclohexane extraction followed by 1:9 dilution with methanol and analysis in a high-performance liquid chromatograph with UV photodiode-array detector (PerkinElmer Series 200 UV-Vis HPLC system). AVS was determined by way of hot acid digestion using $5 \mathrm{~mL}$ of $5 \mathrm{M} \mathrm{HCl}$ and $3 \mathrm{~mL}$ of ethanol, with the resultant $\mathrm{H}_{2} \mathrm{~S}$ trapped in $0.15 \mathrm{M}$ $\mathrm{NaOH}$ and measured photometrically via methylene blue in a UV-Vis Spectrophotometer (Varian Cary 1E). CRS was determined by also starting with hot acid digestion followed by reduction with $1 \mathrm{M} \mathrm{CrCl}_{2}$ solution and photometrical determination of $\mathrm{H}_{2} \mathrm{~S}$. All chemicals were analytical grade.
To determine acidity deposition in the lake sediment, the content of $\mathrm{S}^{0}, \mathrm{FeS}$ and $\mathrm{FeS}_{2}$ was stoichiometrically converted to proton- and thus acidity-equivalents according to the following chemical equations with $\mathrm{CH}_{2} \mathrm{O}$ and $\mathrm{FeOOH}$ as simplified proxies for organic substances and ferric (oxy)hydroxides, respectively:

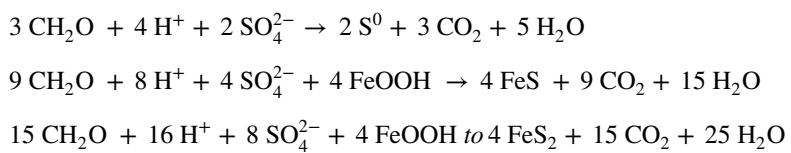

Accordingly, formation of $1 \mathrm{~mol} \mathrm{~S} \mathrm{~S}^{0}, \mathrm{FeS}$, and $\mathrm{FeS}_{2}$ each buffer $2 \mathrm{~mol}$ of protons. Proton equivalents for different sulphur species were summarised for every sediment core and converted to areal proton equivalents $\left[\mathrm{mol} / \mathrm{m}^{2}\right]$ using dry substance content, a specific weight of $\approx 1.5 \mathrm{~kg}$ dry substance per $\mathrm{L}$ and corresponding sediment thickness. Areal proton equivalents for each sediment core were extrapolated to proton equivalents [kmol] for a spatially assigned lake segment surrounding the sampling location for a water depth of $<2 \mathrm{~m}$. The sum of all polygons that featured both a noteworthy sediment layer and measurable sulphur species, thus contributing to acidity deposition, yielded an estimate of the total acidity stored in the lake sediment up until the collecting of sediment cores in 2014, as described by Schäfer et al. (2016).

\section{Mass Balance}

Substance fluxes to and from Knappensee were calculated by multiplying flows with the respective concentration. In addition to acidity as the target substance, other major $(\mathrm{Ca}$, $\mathrm{Mg}$, sulphate) and conservative ( $\mathrm{Na}, \mathrm{K}, \mathrm{Cl}, \mathrm{B})$ substances were used for validation and, if applicable, optimisation of the mass balance. Averaged datasets over a 5-year period (2014-2018) were used to minimise the effect of seasonal, hydraulic, and stochastic fluctuations as well as potential outliers. The time period since 2014 was chosen due to the availability of suitable, complete datasets and because 2013 featured a hundred-year flood event in the early summer after lengthy and continual rains, which could have compromised mass balance calculations. Where larger datasets were available for individual hydrological or hydrochemical components of the mass balance, the complete datasets up to the present day were, for the sake of completeness, scrutinised for consistency (data not shown).

Surface flow to Knappensee includes the treatment plant discharge (TPD), two small tributaries (T1 from the north and T2 from the southeast) and runoff water, the latter including surface runoff and discharge from a rainwater retention basin. Surface outflow from Knappensee only occurs via the spillway. Groundwater flow to and from Knappensee was divided into the northern, northeastern, 
Table 1 Input data sources and quality for the mass balance

\begin{tabular}{|c|c|c|c|c|c|c|c|}
\hline & \multicolumn{4}{|l|}{ Inflow } & \multicolumn{3}{|l|}{ Outflow } \\
\hline & $\begin{array}{l}\text { Treatment } \\
\text { plant dis- } \\
\text { charge }\end{array}$ & Tributaries & $\begin{array}{l}\text { Groundwater } \\
\text { inflow }\end{array}$ & Precipitation & $\begin{array}{l}\text { Spillway dis- } \\
\text { charge }\end{array}$ & $\begin{array}{l}\text { Groundwater } \\
\text { outflow }\end{array}$ & $\begin{array}{l}\text { Evapotranspi- } \\
\text { ration }\end{array}$ \\
\hline Hydrology & Measured & Modelled & Modelled & Official records & Modelled & Modelled & Modelled \\
\hline $\begin{array}{l}\text { Sampling inter- } \\
\text { val }\end{array}$ & Monthly & $\begin{array}{l}\text { Individual sam- } \\
\text { plings }\end{array}$ & Yearly & Literature & Bimonthly & Yearly & Literature \\
\hline $\begin{array}{l}\text { Expected data } \\
\text { quality }\end{array}$ & Excellent & Poor & Fair & Excellent & Excellent & Fair & Excellent \\
\hline
\end{tabular}

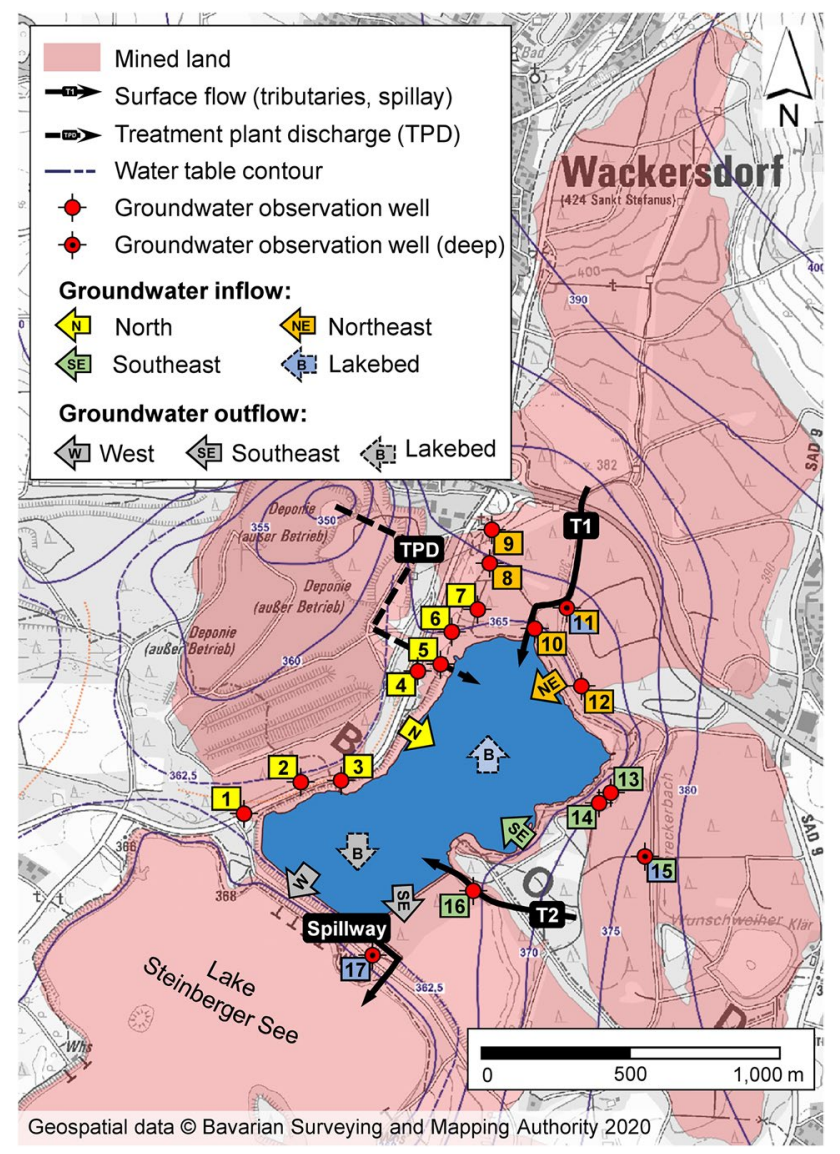

Fig. 4 Hydrogeology of Lake Knappensee with inflow and outflow pathways

southeastern, and western shoreline as well as through the lakebed. Lastly, precipitation to and evapotranspiration from the lake surface were considered (Fig. 4).

Substance concentrations of surface water fluxes (treatment plant discharge, spillway discharge, tributaries) were derived from the respective hydrochemical monitoring. Substance concentrations for rainwater and runoff water were estimated using the basic rainwater signature according to Appelo and Postma (2005), based on the assumptions that, relative to mining-influenced water, only negligible mineralisation and/or acidification occurred during the brief flow times to the pit lake, and that evapotranspiration only removes "pure" water from the lake. For characterisation of the groundwater inflow to Knappensee from the surrounding mined land, suitable observation wells were selected based on specific criteria such as proximity to the pit lake in a direct groundwater flow path from the surrounding catchment, applicable depth of the filter section, and complete datasets for 2014-2018. Averaged datasets were used for observation wells situated in the groundwater flow path from the north (1-7), northeast (8-12), and southeast (13-16). A number of deeper observation wells were chosen to represent groundwater inflow via the lakebed $(11,15,17)$, as marked in Fig. 4. Regarding outflow from Knappensee, it should be noted that substance concentrations measured at the spillway were used to characterise both surface- and groundwater outflow based on the simplistic assumption of a homogeneous, mixed body of water. The matrix in Table 1 shows sources and quality of the database for the simple mass balance. Obviously, the small tributaries are the most likely error source, although the effect may be limited by the relatively low flow rates and mineralisation compared to mining-influenced waters.

\section{Results and Evaluation}

\section{Hydrology, Hydrochemistry and Hydrogeology}

After reaching the predetermined lake level in 1982, the water level in Knappensee was only slightly adjusted in $1998 / 1999$ by $+10 \mathrm{~cm}$, which, however, slowly receded to the original water level by 2007. Since then, the lake level was stable due to the free spillway, with relatively small fluctuations of usually less than $\pm 0.1 \mathrm{~m}$ to date, resulting in stable environmental circumstances in both littoral and sediment. No major water level fluctuations, flushing events, or incidents were recorded except for a temporary rise of the water table after the severe hundred-year flood in 2013. As shown in Fig. 4, Knappensee is situated in the central part of the Tertiary trench system that formerly comprised the lignite seams, covering a catchment area 
Table 2 Water budget of Knappensee: averaged und total inflow for the period 2014-2018

\begin{tabular}{|c|c|c|c|c|c|c|c|c|c|}
\hline & \multirow[t]{2}{*}{ Rainwater } & \multirow[t]{2}{*}{$\mathrm{T} 1$} & \multirow[t]{2}{*}{$\mathrm{T} 2$} & \multirow[t]{2}{*}{ Surface runoff } & \multirow{2}{*}{$\begin{array}{l}\text { Treatment plant } \\
\text { discharge }\end{array}$} & \multicolumn{4}{|c|}{ Groundwater inflow } \\
\hline & & & & & & North & Northeast & Southeast & Lakebed \\
\hline Average flow rate $[\mathrm{L} / \mathrm{s}]$ & 9.5 & 2.1 & 3.2 & 2.7 & 7.8 & 0.6 & 3.7 & 2.6 & 1.8 \\
\hline$\Sigma$ inflow $\left[10^{3} \times \mathrm{m}^{3}\right]^{\mathrm{a}}$ & 1504 & 335 & 499 & 431 & 1238 & 99 & 589 & 402 & 279 \\
\hline
\end{tabular}

${ }^{\mathrm{a} C}$ Considering 365.25 days per year over a 5-year period

of $3-4 \mathrm{~km}^{2}$, which corresponds to $\approx 50 \%$ of the mining districts' diffuse AMD. The groundwater table contours derived from the groundwater flow model show that groundwater inflow to the pit lake predominantly originates from and/or passes through backfilled former opencast segments.

Averaged data for inflow and outflow to and from Knappensee for the period 2014-2018 are compiled in Tables 2 and 3, respectively. Table 2 shows that inflow consists of rainwater, runoff, and surface inflow (together $\approx 50 \%$ ), as well as treatment plant discharge and groundwater inflow $(\approx 25 \%$ each). Table 3 shows that outflow occurs predominantly via the spillway $(\approx 56 \%)$ and evapotranspiration $(\approx 42 \%)$. Groundwater outflow is comparatively low $(\approx 2 \%)$ since Knappensee is a shallow pit lake and most of the lake discharges via the spillway. The water balance yielded an overall averaged inflow of $53.7 \times 10^{5} \mathrm{~m}^{3} / \mathrm{a}$ and an outflow of $54.3 \times 10^{5} \mathrm{~m}^{3} / \mathrm{a}$, which was within the computational accuracy of the model (or respective input data) and thus considered acceptable in view of the scale of the natural system in question. By using the lake volume of $1.2 \times 10^{6} \mathrm{~m}^{3}$ and throughflow of 1.0 to $1.1 \times 10^{6} \mathrm{~m}^{3} / \mathrm{a}$, the theoretical residence time of water in Knappensee was calculated as 1.1-1.2 years. Model results for the spillway discharge were in good accordance with field-derived, daily measured discharge (relative difference $-5.9 \%$ ). Model results of the treatment plant discharge (average $7.7 \mathrm{~L} / \mathrm{s}$ ) were in good accordance with the continuously measured average discharge rate $(7.8 \mathrm{~L} / \mathrm{s})$.

The hydrochemical database for Knappensee was relatively poor before 1992, yet very good afterwards. Lake pH started to increase in about 1999 or 2000 from highly acidic ( $\mathrm{pH} 3.5)$ and reached circumneutral levels $(\mathrm{pH} \approx 7)$ around the year 2011 (Fig. 5). The pH increased slowly until 2007 due to the iron(III)- and aluminium buffer systems at $\mathrm{pH}<4.5$, followed by a fast increase to the circumneutral range with only weak buffer systems (e.g. ion exchange, mineral transformations) followed by the bicarbonate buffer system (Totsche et al. 2003). Simultaneously acidity and iron concentration decreased substantially from peaks in 1992 and 2001 at up to $1.4 \mathrm{mmol} / \mathrm{L}$ and $3.5 \mathrm{mg} / \mathrm{L}$ to $\approx 0 \mathrm{mmol} / \mathrm{L}$ and $<0.5 \mathrm{mg} / \mathrm{L}$, respectively (Fig. 5). Since 2010, Knappensee has displayed circumneutral $\mathrm{pH}$ and a stable acid-base equilibrium. Nonetheless, continuous inflow of diffuse AMD
Table 3 Water budget of Knappensee: averaged und total outflow for the period 2014-2018

\begin{tabular}{llllll}
\hline & $\begin{array}{l}\text { Evapo- } \\
\text { transpira- } \\
\text { tion }\end{array}$ & $\begin{array}{l}\text { Spillway } \\
\text { discharge }\end{array}$ & & \multicolumn{2}{c}{ Groundwater outflow } \\
\cline { 5 - 6 } & & West & Southeast & Lakebed \\
\hline $\begin{array}{l}\text { Average flow rate } \\
{[\mathrm{L} / \mathrm{s}]}\end{array}$ & 14.3 & 19.3 & 0.7 & 0.01 & 0.1 \\
$\begin{array}{c}\Sigma \text { outflow } \\
{\left[10^{3} \times \mathrm{m}^{3}\right]^{\mathrm{a}}}\end{array}$ & 2263 & 3041 & 109 & 2 & 14 \\
\hline
\end{tabular}

${ }^{\mathrm{a} C}$ Considering 365.25 days per year over a 5-year period

was still evident due to elevated, stable sulphate concentration (Fig. 5) as well as extremely acidic pH (2.5-4.0) observed in near-shore groundwater seeps and lake water in very confined areas directly adjacent to pits and dumps, especially along the northeastern shoreline ( $\mathrm{pH}$ mappings displayed in supplemental Fig. S-1).

Discharge of the chemical water treatment plant was consistently circumneutral (pH 7.8 \pm 0.1$)$ and slightly netalkaline (acidity $\approx-0.18 \mathrm{mmol} / \mathrm{L}$ ) due to the addition of lime slurry. Total iron concentrations were consistently below $1.0 \mathrm{mg} / \mathrm{L}$.

Monitoring of surrounding groundwater observation wells showed that most of the mined and backfilled land is heavily affected by pyrite oxidation. Groundwater observation wells in the immediate vicinity of Knappensee showed moderately acidic $\mathrm{pH}$-values around 6.0 yet predominantly increased acidity with an overall interquartile range (25-75\% quartiles) of $0.03-7.2 \mathrm{mmol} / \mathrm{L}$ up to a maximum of $47.7 \mathrm{mmol} / \mathrm{L}$, which was mostly attributable to elevated iron concentrations up to and above $1000 \mathrm{mg} / \mathrm{L}$. This, together with consistently increased sulphate concentrations, shows that pyrite oxidation is persisting in the waste rock dumps surrounding Knappensee. Groundwater chemistry in individual observation wells has been relatively stable throughout the years, albeit some (stochastic) fluctuations, and no clear trends, neither rising nor falling, are discernible. Nevertheless, some variation was observed between individual observation wells and clustered groundwater inflows (N, NE, SE, lakebed) as displayed in Table 4 and supplemental Fig. S-2.

Sampling campaigns of the small intermittent tributaries in 2019 showed moderately mineralised water chemistry. 
T1 displayed a mining-influenced character during the first sampling with elevated conductivity $(1830 \mu \mathrm{S} / \mathrm{cm})$, sulphate $(787 \mathrm{mg} / \mathrm{L})$, total iron $(81 \mathrm{mg} / \mathrm{L})$, and acidity $(2.15 \mathrm{mmol} / \mathrm{L})$ since the ditch passes through a waste rock dump. In contrast, the second campaign showed much less mineralisation, with lower conductivity $(651 \mu \mathrm{S} / \mathrm{cm})$, sulphate $(215 \mathrm{mg} / \mathrm{L})$, total iron $(0.3 \mathrm{mg} / \mathrm{L})$, and acidity $(0.26 \mathrm{mmol} / \mathrm{L})$, presumably due to rainy conditions in the two previous days. T2 displayed slightly elevated concentrations of various elements and nutrients (e.g. nitrate, TOC), being episodically fed by a cascade of fishponds. Again, the second sampling showed less mineralisation than the first sampling (684 and $912 \mu \mathrm{S} /$ $\mathrm{cm}$, respectively), yet little in the way of acidity in either case with $0.01 \mathrm{mmol} / \mathrm{L}$ each. This illustrates the hydrochemical variability of the small tributaries discharging to Knappensee. Both T1 and T2 were, compared to the considerably and continuously mining influenced groundwater and treatment plant discharge, considered rather negligible regarding overall substance fluxes, yet difficult to characterise in the time available, and thus no further samplings were made.
Water quality of all mass balance components (inflow and outflow) is compiled in Table 4 for the time period 2014-2018. Statistical evaluation of the hydrochemical monitoring of treatment plant discharge, groundwater inflows, and lake outflow for the period 2014-2018 is displayed in supplemental Fig. S-2.

\section{Sediment}

Due to the lack of an organic-rich layer and/or disturbances or damages during sampling or analysis, cores $2,6,7$, and 11 and cores 3,10 , and 15 had to be excluded from (chemical) evaluation of the 2013 and 2014 sediment sampling campaigns, respectively. Cores subjected to further analyses were reduced to $n=11$ and $n=12$ for 2013 and 2014, respectively. Sediment heights could, however, be measured and used for calculation of sedimentation rates in all cases.

Sediment thickness appeared to be spatially heterogeneous across the lake with interquartile ranges from $16.5-29.4 \mathrm{~cm}$ in the northern littoral water zone $(16$
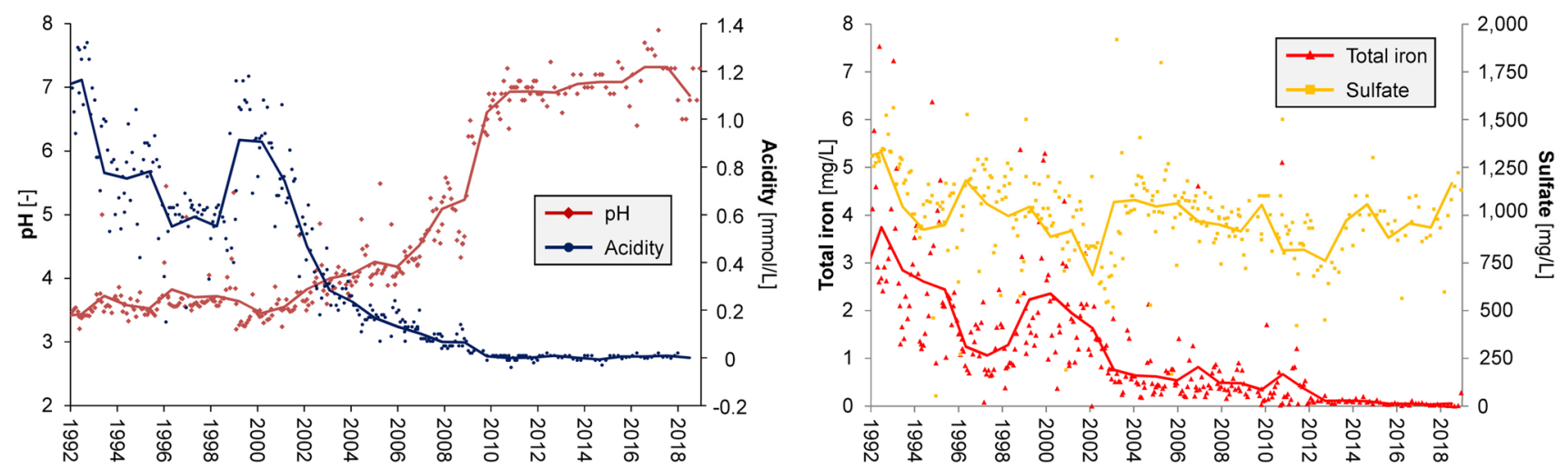

Fig. 5 Development of pH and acidity as well as total iron and sulphate in Lake Knappensee 1992-2019 ( $\mathrm{n}=294$; solid lines indicate the calculated annual average)

Table 4 Mass balance parameters in inflow and outflow to and from Knappensee for the period 2014-2018 (average \pm standard deviation of treatment plant and spillway discharges; interquartile ranges for groundwater inflow; individual tributary measurements) with number of samples indicated in the first column

\begin{tabular}{|c|c|c|c|c|c|c|c|c|}
\hline Monitoring & $\mathrm{Na}(\mathrm{mg} / \mathrm{L})$ & $\mathrm{K}(\mathrm{mg} / \mathrm{L})$ & $\mathrm{Cl}(\mathrm{mg} / \mathrm{L})$ & $\mathrm{B}(\mu \mathrm{g} / \mathrm{L})$ & $\mathrm{Ca}(\mathrm{mg} / \mathrm{L})$ & $\mathrm{Mg}(\mathrm{mg} / \mathrm{L})$ & $\mathrm{SO}_{4}(\mathrm{mg} / \mathrm{L})$ & Acidity $(\mathrm{mmol} / \mathrm{L})$ \\
\hline Treatment plant discharge $(\mathrm{n}=60)^{\mathrm{a}}$ & $140 \pm 13$ & $65 \pm 6$ & $185 \pm 34$ & $872 \pm 125$ & $584 \pm 39$ & $100 \pm 13$ & $1795 \pm 265$ & $-0.2 \pm 0$ \\
\hline $\mathrm{T} 1(\mathrm{n}=2)$ & $30.8 / 48.3$ & $6.0 / 9.1$ & $47.5 / 71.7$ & $0 / 60$ & $70.4 / 222$ & $13.7 / 33.7$ & $215 / 787$ & $0.26 / 2.15$ \\
\hline $\mathrm{T} 2(\mathrm{n}=2)$ & $36.3 / 47.6$ & $7.4 / 7.9$ & $63.2 / 75.1$ & $130 / 190$ & $82.1 / 132$ & $6.9 / 7.7$ & $193 / 298$ & $0.01 / 0.01$ \\
\hline Rainwater, runoff & 1.2 & 0.3 & 1.0 & 0 & 1.1 & 0.5 & 5.0 & 0 \\
\hline GW-inflow north $(n=34)$ & $78.5-172$ & $7.2-15.6$ & $51.6-300$ & $70.0-240$ & $75.7-258.5$ & $10.7-32.4$ & $183-1021$ & $0.0-13.2$ \\
\hline GW-inflow northeast $(n=25)$ & $9.7-18.6$ & $8.8-15.0$ & $25.0-47.9$ & $67.5-198$ & $207-384$ & $29.0-63.2$ & $498-1560$ & $2.7-8.1$ \\
\hline GW-inflow southeast $(n=20)$ & $11.4-19.5$ & $9.4-15.0$ & $9.9-50.2$ & $52.0-285$ & $177-423$ & $36.0-62.4$ & $774-1703$ & $0.2-5.8$ \\
\hline GW-inflow lakebed $(n=15)$ & $19.0-42.5$ & $12.3-21.3$ & $22.0-89.1$ & $135-325$ & $262-590$ & $38.9-71.3$ & $1022-1770$ & $3.0-7.6$ \\
\hline Spillway discharge $(n=30)$ & $68.6 \pm 7.8$ & $31.2 \pm 6.6$ & $106 \pm 14$ & $425 \pm 71$ & $322 \pm 40$ & $46 \pm 6.5$ & $956 \pm 131$ & $0.003 \pm 0.01$ \\
\hline
\end{tabular}

${ }^{\mathrm{a}} \mathrm{For} \mathrm{Cl} \mathrm{n}=54$; for $\mathrm{B} \mathrm{n}=41$ 
measurements) to $14.2-19.7 \mathrm{~cm}$ in the northern shallow water zone ( 8 measurements) and $10.1-15.0 \mathrm{~cm}$ in the southern littoral zones (6 measurements). However, this was not tested statistically. The overall average sediment thickness was $\approx 20 \mathrm{~cm}$. Dry mass content largely ranged between $10-40 \%$ and dry matter was composed almost entirely (>90\%) of fine materials $<2 \mathrm{~mm}$. Sediments were overlaid and/or interspersed with organic substances, predominantly roots and plant debris. The bulk of the sediment was greyishblack with brownish and sand-coloured layers or marbling. Several cores featured distinct ocherous depositions on or throughout the top layer. Photographs of all 2014 sediment cores are provided in supplemental Fig. S-3. Based on the heights of sediment layers in the 2013 and 2014 cores, sedimentation rates were determined for the relevant period from the end of flooding to the sampling year. Average sedimentation rates of $7.5( \pm 4.0)$ and $5.8( \pm 2.5) \mathrm{mm} / \mathrm{a}$ were calculated for the northern littoral ( $<1 \mathrm{~m} \mathrm{depth})$ and open water (1-2 m depth) reaches, respectively, as well as $3.8( \pm 1.0)$ $\mathrm{mm} / \mathrm{a}$ for the southern littoral zones. Knappensee sediment accumulation rates in the order of a few millimetres or centimetres per year are in accordance with literature values for freshwater lakes (e.g. Benoy and Kalff 1999; Xu et al. 2017) as well as natural and artificial surface-flow wetlands (e.g. Craft and Richardson 1993; Harter and Mitsch 2003; Mitsch et al. 2014). Both sediment sampling campaigns broadly confirmed the initial assumption that sediment accumulation prevailed in the littoral zones and decreased considerably with increasing water depth and towards the narrower southern littorals.

Laboratory analyses of the sediment cores sampled across Knappensee showed distinct accumulations of typical mine water analytes, predominantly iron but also aluminium, sulphur, and organic carbon in the sediment, with other elements and particularly contaminants negligible or below detection limit. All elements were unevenly distributed across the lake. Sulphur was predominantly found to be in a reduced state as $\mathrm{S}^{2-}$ and $\mathrm{S}_{2}{ }^{2-}$ plus small amounts of $\mathrm{S}^{0}$. It is important to note that the presence of acid volatile and elementary sulphur indicate recent reduction processes. The highest contents of sulphide and/or pyritic sulphur $(200 \mu \mathrm{mol} / \mathrm{g}$ or more) were found in sediment cores 1 , $4,5,6,7,9,11$, and 14. Calculation of proton equivalents from sulphur species and areal proton equivalents for the sediment cores as well as subsequent extrapolation of total proton equivalents per lake polygon are provided in supplemental Table S-1, following Schäfer et al. (2016). Based on these findings, Schäfer et al. (2016) estimated that about $6400 \mathrm{kmol}$ of acidity were stored in the lake's sediment by 2014, with distribution across the lake displayed in Fig. 6. This number is a relatively conservative estimate considering that only 12 out of 15 cores (and thus only respective polygons with $\approx 350,000 \mathrm{~m}^{2}$, i.e. $64 \%$ of the lakes' area) were included in the calculations and no investigations were conducted in the deeper reaches (roughly $>2 \mathrm{~m}$ water depth) of the lake. If these unconsidered, extensive areas of Knappensee feature noteworthy volumes of sediment containing reduced sulphur species, the above estimate would increase substantially, e.g. by $\approx 6000 \mathrm{kmol}$, assuming an average sediment core acidity of $\approx 30 \mathrm{~mol} / \mathrm{m}^{2}$ for the remaining $\approx 200,000 \mathrm{~m}^{2}$.

The presence of substantial amounts of sulphide, pyritic, and elemental sulphur in nearly all sediment cores was in accordance with visual and organoleptic observations of reduced sulphur species in Knappensee's near-shore sediment. The considerable biological generation and deposition of reduced sulphur species is taken as evidence for the presence of SRB, since noteworthy sulphate reduction rates in limnological systems are only known to occur as a result of dissimilatory sulphate reduction (Holmer and Storkholm 2001; Knöller et al. 2004).

\section{Mass Balance Calculations}

In a first step, calculations were made for the aforementioned conservative, highly soluble elements $(\mathrm{Na}, \mathrm{K}, \mathrm{Cl}, \mathrm{B})$ to validate suitability of the database for mass balance calculations (results provided in supplemental Table S-2). Results over the five-year period were similar and inflow mass exceeded the outflow mass for all four elements with relative errors of $+18.0 \%$ for $\mathrm{Na},+6.9 \%$ for $\mathrm{K},+18.0 \%$ for $\mathrm{Cl}$, and $+5.3 \%$ for B. With all substances featuring a mass surplus in the inflow, there is a good cause to believe that substance fluxes not only via the tributaries, but also via the mostly, but not exclusively mining-influenced groundwater were somewhat overestimated. This is hardly surprising with most observation wells surrounding the pit lake specifically installed to monitor contaminant transport in the flow path from backfilled opencast segments to the central pit lake. Consequently, groundwater from areas that are only moderately or not at all affected by mining activities (e.g. remaining Tertiary segments, deep Triassic layers, near-surface recultivation topsoil layers) was likely underrepresented, leading to overestimation of substance transport to Knappensee in the simple mass balance.

Therefore, in a second step, a sensitivity analysis was conducted for the two most likely mass balance error sources according to Table 1, namely the small tributaries and groundwater inflow. In a first scenario, interquartile ranges (25-75\% quartiles) were used for groundwater inflow together with the lower and higher values measured for the tributaries. In a second scenario, the $40-60 \%$ quintiles were used together with the lower and higher values 


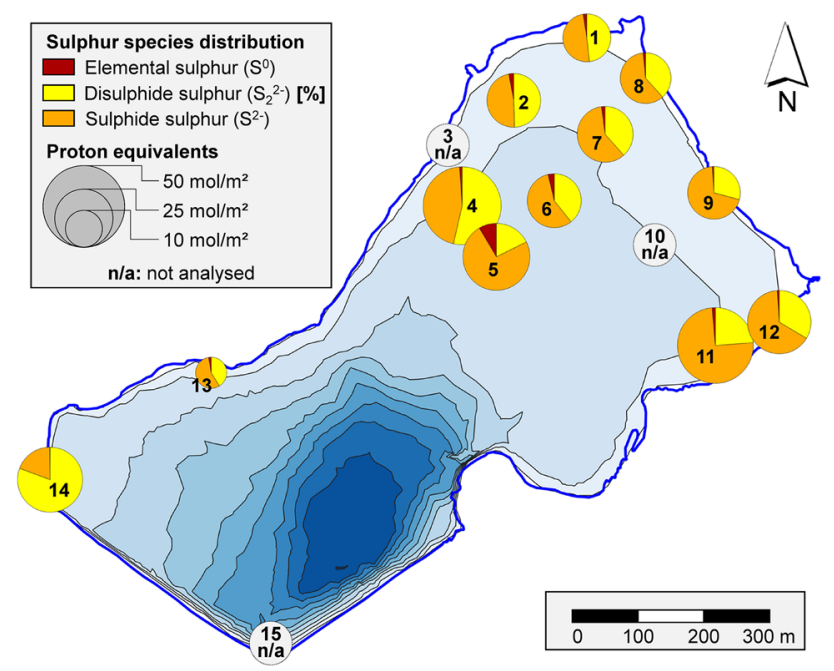

Fig. 6 Areal proton equivalents stored in the sediment of Lake Knappensee as estimated from sediment core analyses

measured for the tributaries. Results are provided in supplemental Table S-2. For the four conservative elements, the $25 \%$ quartile and $40 \%$ quintile scenarios resulted in relative errors between -8 and $+7 \%$, whereas the $60 \%$ quintile and $75 \%$ quartile scenarios resulted in relative errors between +8 and $+19 \%$. Altogether, the sensitivity analysis shows how much the mass balance, especially the acidity balance, may vary depending on groundwater chemistry. Lower concentrations (25\% quartile and $40 \%$ quintile) considerably reduced relative errors for the four conservative elements. Likely reasons for a surplus of most elements in both original mass balance and further scenarios include, but are not limited to: (1) temporal and spatial variability of mass fluxes via the small tributaries due to intermittent flow and susceptibility to rain-/ stormwater effects that are insufficiently described by the limited data; (2) heterogeneity of groundwater chemistry around the pit lake, with overall mineralisation and substance concentrations between observation wells varying considerably by up to orders of magnitude; (3) integration of ions into biological or geochemical cycles within the pit lake (e.g. sorption, co-precipitation, plant uptake and assimilation, sediment processes); and (4) boosting of $\mathrm{Na}$ and $\mathrm{Cl}$ mass transport due to road salt application during snow melting.

Consequently, in a third step, an overall correction factor was calculated as the average of individual correction factors calculated for $\mathrm{Na}, \mathrm{K}, \mathrm{Cl}$, and $\mathrm{B}$ as highly soluble, ubiquitous elements. $\mathrm{Ca}$ and $\mathrm{Mg}$ were not deemed suitable for mass balance correction since first, both elements are known to be closely associated and thus co-precipitated with hydrous ferric oxides or Mn (hydr)oxides (Ingri and Widerlund 1994), and second, both elements were close to the saturation level for precipitation of respective sulphate or carbonate minerals in some inflows, as determined by a quick PHREEQC survey (data not shown). Nevertheless, mass balances for $\mathrm{Ca}$ and $\mathrm{Mg}$ as well as sulphate were calculated in addition to acidity to double-check the validity of the correction and receive an approximate impression of the extent of a potential $\mathrm{Ca}$ and $\mathrm{Mg}$ deficit in the outflow.

Correction factors for $\mathrm{Na}, \mathrm{K}, \mathrm{Cl}$, and $\mathrm{B}\left(\mathrm{F}_{\mathrm{Na}}, \mathrm{F}_{\mathrm{K}}, \mathrm{F}_{\mathrm{Cl}}\right.$, $F_{B}$ ) were calculated from changes in overall mass inflow and outflow to and from Knappensee, as illustrated for $\mathrm{Na}$ :

$F_{N a}=\frac{\left.\sigma\left(c(N a)_{o u t}\right) \times Q_{o u t}\right)}{\left.\sigma\left(c(N a)_{\text {in }}\right) \times Q_{\text {in }}\right)}$

Following this, the average overall correction factor, $\mathrm{F}_{\mathrm{Av}}$, was calculated as the average of the individual correction factors $\mathrm{F}_{\mathrm{Na}}, \mathrm{F}_{\mathrm{K}}, \mathrm{F}_{\mathrm{Cl}}$, and $\mathrm{F}_{\mathrm{B}}$. The overall correction factor was used for correction of all mass balances by calculating the respective additional outflow mass, as illustrated for $\mathrm{Na}$ :

$\Delta m(N a)_{\text {out }}=\sigma\left(c(N a)_{\text {in }} \times Q_{\text {in }} \times F_{A v}\right)$

An overall correction factor of 0.89 was obtained, which is acceptable for a large-scale, natural open system such as Knappensee. Results of the corrected mass balance are compiled in Table 5. Relative errors of the four conservative elements were minimised to $+5.7 \%$ for $\mathrm{Na},-4.7 \%$ for $\mathrm{K},+5.8 \%$ for $\mathrm{Cl}$, and $-6.2 \%$ for $\mathrm{B}$. As expected, acidity shows a substantial surplus of $5936 \mathrm{kmol}$ in the lake inflow over the period 2014-2018, which converts to $1187 \mathrm{kmol} / \mathrm{a}$. Considering the lake's throughput of $1.2 \times 10^{6} \mathrm{~m}^{3} / \mathrm{a}$, this corresponds to an average acidity of $0.99 \mathrm{mmol} / \mathrm{L}$ in the lake outflow if no reactions or processes would take place that eventually immobilised acidity in the pit lake. This figure agrees well with measured pre-neutralisation acidity levels in Knappensee (Fig. 5). The range of the inflow acidity surplus, as determined by the sensitivity analysis, was 2386-10,975 kmol (supplemental Table S-2), corresponding to an average acidity of $0.40-1.83 \mathrm{mmol} / \mathrm{L}$.

$\mathrm{Ca}, \mathrm{Mg}$, and sulphate show a surplus of $18 \mathrm{t} / \mathrm{a}, 6.2 \mathrm{t} / \mathrm{a}$, and 122 t/a, respectively. Considering overall mass fluxes during 2014-2018 (Table 5), these figures are easily conceivable. If sulphate reduction was assumed as the sole reason for acidity consumption (with no other process conceivable for this amount), $46.6 \%$ of the sulphate surplus would be explained by the acidity surplus with $1 \mathrm{~mol}$ sulphate consumed to neutralise 2 mol of protons ( Koschorreck and Tittel 2007). Most of the remaining sulphate surplus could be explained by precipitation of $\mathrm{Ca} / \mathrm{Mg}$-sulphates (35 and $20 \%$, respectively) or other processes such as sorption by organic matter.

Altogether, the rough substance flow analysis of Knappensee clearly shows a large acidity surplus, estimated at 
$\approx 1190 \mathrm{kmol} / \mathrm{a}$ for $2014-2018$, in the inflow, and, based on analysis of sediment cores, substantial amounts of reduced sulphur species and thus acidity. The acidity stored in in the sediment is conservatively estimated as at least $6400 \mathrm{kmol}$ from the onset of neutralisation (presumably around 1999/2000) until sampling of the sediment cores in 2014. By adding the cumulative acidity in the lake's outflow between around $2000 / 2001$ and 2014 , estimated at $\approx 8000 \mathrm{kmol}$ by Schäfer et al. (2016), acidity inflow to Knappensee between the turn of the millennium and 2014 is roughly estimated at $14,400 \mathrm{kmol}$. This converts to $960 \mathrm{kmol} / \mathrm{a}$. As the two estimates for time periods 2000-2014 and 2014-2018 are not only on the same order of magnitude, but in relatively good agreement considering the scale and complexity of the natural open system, the results of this study strongly indicate that natural sulphate reduction was the driving force of in-lake neutralisation of Knappensee.

\section{Discussion}

Both the hydrological and hydrochemical databases for a large-scale natural system were inevitably fraught with uncertainties, especially given the considerable spatial differences in mineralisation and acidification potential of groundwater discharging to Knappensee. Whereas ascertained values were derived from high-resolution monitoring of discharge rates and (bi)monthly samplings, both surface and groundwater inflow to the pit lake were much harder to characterise with justifiable expenditure (Table 1). Similarly, proton equivalents calculated from sediment-sulphur analysis were ascertained values, whereas the ensuing extrapolation to lake polygons was fraught with uncertainty due to unknown heterogeneity of sediment distribution throughout the extensive shallow areas. Notwithstanding this, the simple mass balance approach yielded reasonable estimates for substance fluxes to and from the lake. Remaining uncertainties are acceptable in the first step of an acidity transport assessment in the former lignite district. In this context, it is worth mentioning that a similar, albeit much slower trend towards neutralisation as observed in Knappensee is currently observed in the subsequent much larger and deeper pit lake in the two-lake cascade "Steinberger See" (currently pH 5-6) (Nixdorf and Ramm 2016). Similar sediment samplings are currently underway in the Steinberger See to investigate potential acidity immobilisation not only in shallow water zones, but also in the monimolimnion or hypolimnion of this deeper pit lake. Following this, the regional acidity transport model will be updated for the twolake cascade in due consideration of natural biogeochemical processes to holistically model the acidity fluxes in the postmining landscape.

Table 5 Results of the corrected mass balance

\begin{tabular}{|c|c|c|c|c|c|c|c|c|}
\hline & $\mathrm{Na}(\mathrm{kg})$ & $\mathrm{K}(\mathrm{kg})$ & $\mathrm{Cl}(\mathrm{kg})$ & $\mathrm{B}(\mathrm{kg})$ & $\mathrm{Ca}(\mathrm{kg})$ & $\mathrm{Mg}(\mathrm{kg})$ & $\mathrm{SO}_{4}(\mathrm{~kg})$ & Acidity $(\mathrm{kmol})$ \\
\hline \multicolumn{9}{|l|}{ Inflow } \\
\hline Treatment plant discharge & 173,697 & 80,625 & 229,464 & 1079 & 722,822 & 123,422 & $2,221,957$ & -223 \\
\hline $\mathrm{T} 1$ & 13,230 & 2526 & 19,937 & 20 & 48,905 & 7928 & 167,590 & 5 \\
\hline $\mathrm{T} 2$ & 20,917 & 3814 & 34,479 & 80 & 53,376 & 3617 & 122,409 & 87 \\
\hline Surface runoff & 495 & 108 & 431 & 0 & 474 & 215 & 2154 & 0 \\
\hline GW north & 11,965 & 1322 & 20,037 & 16 & 19,192 & 3079 & 89,080 & 836 \\
\hline GW northeast & 22,746 & 7338 & 63,234 & 90 & 160,257 & 26,079 & 605,758 & 3135 \\
\hline GW southeast & 6609 & 4919 & 13,517 & 65 & 128,938 & 18,454 & 469,131 & 1332 \\
\hline GW lakebed & 8678 & 4793 & 18,146 & 67 & 114,730 & 14,322 & 409,189 & 1524 \\
\hline Precipitation & 1729 & 376 & 977 & 0 & 1654 & 1504 & 7519 & 0 \\
\hline$\Sigma$ Mass inflow 2014-2018 & 260,066 & 105,819 & 400,221 & 1418 & $1,250,349$ & 198,619 & $4,094,786$ & 6697 \\
\hline \multicolumn{9}{|l|}{ Outflow } \\
\hline Spillway discharge & 208,685 & 94,886 & 320,912 & 1292 & 980,079 & 139,795 & $2,905,472$ & 9 \\
\hline GW southeast & 108 & 49 & 167 & 1 & 509 & 73 & 1508 & 0 \\
\hline GW west & 7472 & 3398 & 11,491 & 46 & 35,094 & 5006 & 104,036 & 0 \\
\hline GW lakebed & 942 & 428 & 1449 & 6 & 4425 & 631 & 13,118 & 0 \\
\hline Evapotranspiration & 0 & 0 & 0 & 0 & 0 & 0 & 0 & 0 \\
\hline$\Delta \mathrm{m}$ & 29,167 & 11,868 & 44,886 & 159 & 140,231 & 22,276 & 459,245 & 751 \\
\hline$\Sigma$ Mass outflow 2014-2018 & 246,375 & 110,629 & 378,905 & 1504 & $1,160,337$ & 167,781 & $3,483,379$ & 760 \\
\hline Balance (inflow minus outflow) & 13,691 & -4810 & 21,316 & -85.7 & 90,012 & 30,839 & 611,408 & 5936 \\
\hline Relative error [\%] & +5.7 & -4.7 & +5.8 & -6.2 & +7.9 & +17.9 & +17.2 & $\mathrm{n} / \mathrm{a}^{\mathrm{a}}$ \\
\hline
\end{tabular}

${ }^{a}$ Not applicable with acidity inflow exceeding outflow by orders of magnitude (outflow deficit) 
Observation of decreasing sediment layer thickness and reduced sulphur content in deeper parts of Knappensee indicate that faster sediment accumulation associated with intensive biomass deposition and decomposition in the extensive shallow water zones promoted not only sulphate reduction in the sediment, but also, and more importantly, the stable immobilisation of reduced sulphur species under anaerobic conditions. This is in agreement with a recent study by Oldham et al. (2019) on ferrous iron fluxes into a pit lake, suggesting that submerged benthic water plants in combination with detritus and sediment accumulation may be a suitable way to decrease groundwater seepage velocities at the sediment-water-interface (transition zone between groundwater and lake) and thus increase mitigation of groundwater-borne ferrous iron and acidity. Limiting access of oxygen and oxidants to the sediment is a vital prerequisite for the development of a reducing and circumneutral environment ideal for SRBs (Geller et al. 2009). Consequently, there is a good cause to believe that continuous discharge of circumneutral water from the treatment plant to Knappensee since the mid1990s might have been a vital trigger and/or the nucleus for natural neutralisation, by (1) creating a local environment suitable for fast growth and distribution of hygrophilous plants directly at and proceeding from the discharge point, which happens to coincide with the extensive and well vegetated shallow water zone (Fig. 1), leading to (2) substantial accumulation and concomitant decomposition of plant litter, which in turn (3) provides a continuous carbon source for thriving SRB that produce alkalinity and thus contribute to mitigation of the acidic groundwater inflow to the pit lake with (4) living plants, plant detritus, and allochthonous sediments stabilising and covering the sediment, thereby protecting the reduced sulphur species from reoxidation. Over time, continual dissimilatory sulphate reduction in the littoral and shallow water zone of the lake resulted in progressive acidity consumption and eventually full neutralisation of the pit lake.

As mentioned in the beginning, this very same mechanism is artificially induced and exploited in anaerobic passive mine water treatment systems such as SAPS by percolating AMD through a buried matrix of organic and alkalinity-generating materials (Burns et al. 2012; Skousen et al. 2017). The similarities between the setup found in Knappensee and anaerobic passive systems are particularly striking with, in either case, a "bioreactor-component" (featuring SRB activity) comprised of an organic-rich substrate of several decimetres beneath a growing layer of sediment and plant debris, which is in turn covered with living hygrophilous plants and a relatively shallow (few decimetres or metres) water column. However, establishment of the processes and especially the self-sustaining substance cycles in a full-scale pit lake is much more complex than in a small passive treatment system. For one thing, the importance of influent neutral water and hydrophyte distribution as a trigger for biogenic de-acidification in Knappensee remains speculative and a subject of follow-up investigations. For another thing, Knappensee is an unusual example of a very shallow polymictic pit lake where acidity is immobilised in the epilimnion, presumably due to favourable environmental and ecologic conditions where reduced sulphur species are covered and protected by a combination of sediments and dense vegetation that naturally developed over several decades. This observation stands in contrast to other pit lakes or respective field trials and to studies postulating a deep meromictic or holomictic pit lake as a prerequisite for stable immobilisation of acidity in the anoxic monimolimnion or hypolimnion as compiled in the Introduction. Since dissimilatory sulphate reduction and subsequent precipitation of metal (mono)sulphides developed naturally, the extensive shallow water zones of Knappensee were regarded as and termed a "natural attenuating pit lake area" (NAPA), schematically illustrated in Fig. 7.

The Knappensee case study indicates that the development of natural biogeochemical processes, already used in small-scale passive treatment systems, is possible in fullscale post-mining waterbodies. Sulphate reduction rates measured and modelled in lignite pit lake sediments at acidic and circumneutral $\mathrm{pH}$, as compiled and modelled by Peiffer (2016), range up to $\approx 260 \mathrm{nmol} / \mathrm{cm}^{3} /$ day, yet mostly fall below $100 \mathrm{nmol} / \mathrm{cm}^{3} /$ day. The estimated sulphate reduction of $1190 \mathrm{kmol} / \mathrm{a}$ over the shallow lake area of $350,000 \mathrm{~m}^{2}$ with the average sediment thickness of $20 \mathrm{~cm}$ in this study yields a purely hypothetical sulphate reduction rate of $\approx 47 \mathrm{nmol} / \mathrm{cm}^{3} /$ day. Although we would like to emphasise that a sound estimation of potential sulphate reduction rates in a large-scale natural system such as Knappensee would require more knowledge, especially of the spatial sedimentary dimensions, this number is, if nothing else, plausible and substantiates the hypothesis that natural in-lake neutralisation is possible if alkalinity generation in a productive and extensive sediment exceeds acidity generation by way of advective ferrous iron inflow. If the necessary environmental conditions and reliable sulphate reduction rates could be identified in following investigations, the concept of NAPAs may be transferable to promote and stabilise progressive mitigation of (diffuse) AMD inevitably generated throughout the catchment area in post-mining waterbodies, and especially artificially created pit lake cascades, on a much larger scale. This could be a substantial contribution to post-mining water management regarding water pollution control, sustainability, and cost/resource saving. 


\section{Conclusions}

Comprehensive monitoring datasets were successfully used to estimate substance fluxes to and from a pit lake via a simple mass balance approach. The estimated acidity inflow rate for the period 2014-2018 agrees with an inflow rate for the period 2000-2014 estimated from acidity deposition in the sediment based on sediment core analyses plus calculated cumulative acidity outflow based on extrapolation of pre-neutralisation acidity levels in the pit lake. The approach may prove useful in the assessment of the hydrochemical state of other mining lakes. Findings of this study have important implications not only for the hydrochemical assessment, but also future management of the pit lake. For example, water level fluctuations (e.g. due to recreational use or flood retention) should be prevented to avoid disturbance of the biogeochemical conditions in littoral sediments, which likely would initiate reoxidation of reduced sulphur species and a consequential acidity flush that would also affect subsequent aquatic systems.

Knappensee is a uniquely well-documented case of inlake neutralisation. Substantial amounts of reduced sulphur species (and thus acidity) were found in the lake's sediment. Our estimates indicate that sulphate reduction has removed about $1000 \mathrm{kmol} / \mathrm{a}$ of acidity. We hypothesise that stable immobilisation was achieved naturally through intensive accumulation and superimposition of organic-rich sediments beneath a thriving ecologic system over several decades in the extensive, well vegetated littoral and shallow water zones. This cover barrier abated or altogether disrupted oxygen- or ferric iron driven redox cycles. Follow-up investigations are necessary to identify the decisive prerequisites, boundary conditions, and limitations, and to quantify substance cycles and reaction rates for application in or calibration of a transport model and as a basis for potential artificial emulation.

Primary objective in pit lake creation and management should be the restoration of a self-sustaining, natural (eco) system to avoid continuous, artificial maintenance of ecological and hydrochemical conditions (e.g. pump-and-treat, nutrient addition, in-lake liming) (Blanchette and Lund 2016). Although pit lakes are usually created relatively deep to effectively compensate for the lack of backfill material, it may, therefore, be worthwhile to consider integration of shallow water zones that may develop into sustainable NAPAs. Consequential in-situ amelioration of AMD-groundwater at the sediment-water-interface would contribute considerably to pit lake water quality. Demand for novel in-situ approaches is evident from the large number of acidic pit lakes worldwide. Since the basic principle has already been proven in small-scale anaerobic mine water treatment wetlands, the next step could be a pilot field trial to reproduce the beneficial environmental conditions observed in Knappensee on a larger scale. As it may take years until the decisive biogeochemical processes are naturally established in a

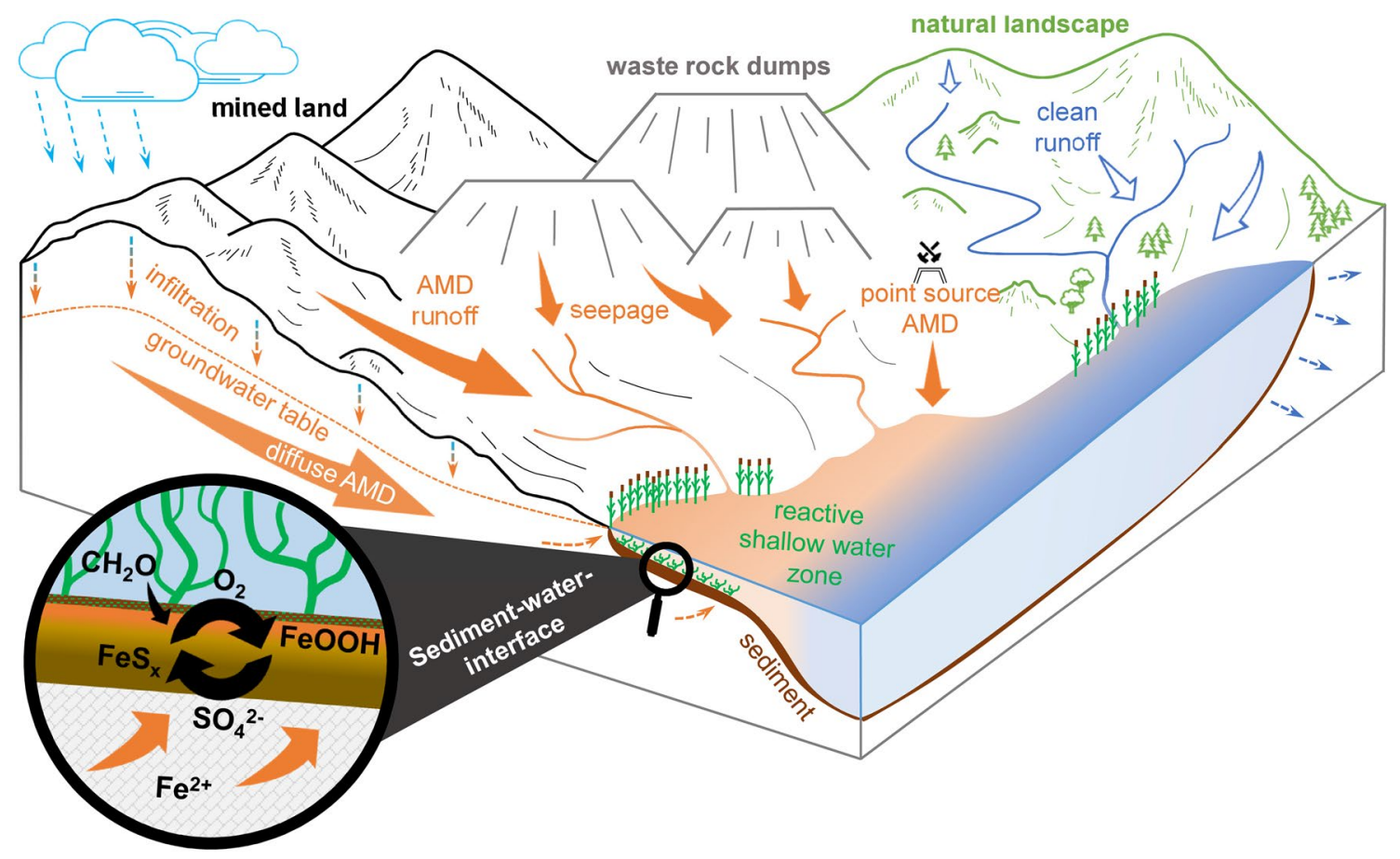

Fig. 7 Schematic of a natural attenuating pit lake area (NAPA) extended from Opitz et al. (2017) 
full-scale pit lake, research should focus on ways to initiate and accelerate these processes on a limnologic scale.

Acknowledgements Open Access funding provided by Projekt DEAL. The project was supported by Uniper Kraftwerke GmbH (Düsseldorf).

Open Access This article is licensed under a Creative Commons Attribution 4.0 International License, which permits use, sharing, adaptation, distribution and reproduction in any medium or format, as long as you give appropriate credit to the original author(s) and the source, provide a link to the Creative Commons licence, and indicate if changes were made. The images or other third party material in this article are included in the article's Creative Commons licence, unless indicated otherwise in a credit line to the material. If material is not included in the article's Creative Commons licence and your intended use is not permitted by statutory regulation or exceeds the permitted use, you will need to obtain permission directly from the copyright holder. To view a copy of this licence, visit http://creativecommons.org/licenses/by/4.0/.

\section{References}

Appelo CAJ, Postma D (2005) Geochemistry, groundwater and pollution, 2nd edn. CRC Press, Boca Raton, ISBN 9780415364287

Becerra CA, López-Luna EL, Ergas SJ, Nüsslein K (2009) Microcosmbased study of the attenuation of an acid mine drainage impacted site through biological sulfate and iron reduction. Geomicrobiol J 26(1):9-20. https://doi.org/10.1080/01490450802599250

Benoy GA, Kalff J (1999) Sediment accumulation and $\mathrm{Pb}$ burdens in submerged macrophyte beds. Limnol Oceanogr 44(4):1081-1090. https://doi.org/10.4319/lo.1999.44.4.1081

Blanchette ML, Lund MA (2016) Pit lakes are a global legacy of mining: an integrated approach to achieving sustainable ecosystems and value for communities. Curr Opin Environ Sustain 23:28-34. https://doi.org/10.1016/j.cosust.2016.11.012

BMU (German Federal Ministry for the Environment, Nature Conservation and Nuclear Safety) (2009) Federal Nature Conservation Act (BNatSchG). Federal Law Gazette 2009 I(51):2542ff

Burns AS, Pugh CW, Segid YT, Behum PT, Lefticariu L, Bender KS (2012) Performance and microbial community dynamics of a sulfate-reducing bioreactor treating coal generated acid mine drainage. Biodegradation 23(3):415-429. https://doi.org/10.1007/ s10532-011-9520-y

Castro JM, Moore JN (2000) Pit lakes: their characteristics and the potential for their remediation. Environ Geol 39(11):1254-1260. https://doi.org/10.1007/s002549900100

Castro JM, Wielinga BW, Gannon JE, Moore JN (1999) Stimulation of sulfate-reducing bacteria in lake water from a former openpit mine through addition of organic wastes. Water Environ Res 71(2):218-223. https://doi.org/10.2175/106143098X121806

Chabbi A (1999) Juncus bulbosus as a pioneer species in acidic lignite mining lakes: interactions, mechanism and survival strategies. New Phytol 144(1):133-142. https://doi.org/10.104 6/j.1469-8137.1999.00503.x

Craft CB, Richardson CJ (1993) Peat accretion and phosphorus accumulation along a eutrophication gradient in the northern Everglades. Biogeochemistry 22(2):133-156. https://doi.org/10.1007/ BF00002708

Delgado-Martin J, Juncosa-Rivera R, Falcón-Suárez I, Canal-Vila J (2013) Four years of continuous monitoring of the Meirama endpit lake and its impact in the definition of future uses. Environ Sci Pollut Res 20(11):7520-7533. https://doi.org/10.1007/s1135 6-013-1618-9
DIN (1997) Water analysis-guidelines for the determination of total organic carbon (TOC) and dissolved organic carbon (DOC). DIN EN 1484:2019-04. https://doi.org/10.31030/3042067

DIN (2005) German standard methods for the examination of water, waste water and sludge - Group $\mathrm{H}$, Part 7: determination of acid and base-neutralizing capacities. DIN 38409-7:2005-12. https:// doi.org/10.31030/9663129

Dowling J, Atkin S, Beale G, Alexander G (2004) Development of the Sleeper Pit Lake. Mine Water Environ 23(1):2-11. https://doi. org/10.1007/s10230-004-0038-y

Fisher TS, Lawrence GA (2006) Treatment of acid rock drainage in a meromictic mine pit lake. J Environ Eng 132(4):516-526. https:// doi.org/10.1061/(ASCE)0733-9372(2006)132:4(515)

Frömmichen R, Kellner S, Friese K (2003) Sediment conditioning with organic and/or inorganic carbon sources as a first step in alkalinity generation of acid mine pit lake water $(\mathrm{pH} 2-3)$. Environ Sci Technol 37(7):1414-1421. https://doi.org/10.1021/es026131c

Frömmichen R, Wendt-Potthoff K, Friese K, Fischer R (2004) Microcosm studies for neutralization of hypolimnic acid mine pit lake water (pH 2.6). Environ Sci Technol 38(6):1877-1887. https://doi. org/10.1021/es034863e

Fyson A, Nixdorf B, Kalin M, Steinberg CE (1998) Mesocosm studies to assess acidity removal from acidic mine lakes through controlled eutrophication. Ecol Eng 10(3):229-245. https://doi. org/10.1016/S0925-8574(98)00007-X

Fyson A, Nixdorf B, Kalin M (2006) The acidic lignite pit lakes of Germany-microcosm experiments on acidity removal through controlled eutrophication. Ecol Eng 28(3):288-295. https://doi. org/10.1016/j.ecoleng.2006.06.012

Geller W, Koschorreck M, Wendt-Potthoff K, Bozau K, Herzsprung P, Büttner O, Schultze M (2009) A pilot-scale field experiment for the microbial neutralization of a holomictic acidic pit lake. J Geochem Explor 100(2-3):153-159. https://doi.org/10.1016/j. gexplo.2008.04.003

Harter SK, Mitsch WJ (2003) Wetlands and aquatic processes-patterns of short-term sedimentation in a freshwater created marsh. J Environ Qual 32(1):325-334. https://doi.org/10.2134/jeq20 03.3250

Holmer M, Storkholm P (2001) Sulphate reduction and sulphur cycling in lake sediments: a review. Freshw Biol 46(4):431-451. https:// doi.org/10.1046/j.1365-2427.2001.00687.x

Ingri J, Widerlund A (1994) Uptake of alkali and alkaline-earth elements on suspended iron and manganese in the Kalix River, northern Sweden. Geochim Cosmochim Acta 58(24):5433-5442. https ://doi.org/10.1016/0016-7037(94)90240-2

ISO (1996a) Soil quality - determination of organic and total carbon after dry combustion (elementary analysis). DIN ISO 10694:199608 (replaced by: DIN EN 15936:2012-11)

ISO (1996b) Soil quality - determination of dry matter and water content on a mass basis - gravimetric method. DIN ISO 11465:199612 (replaced by: DIN EN 15934:2012-11)

ISO (1997) Soil quality-extraction of trace elements soluble in aqua regia. DIN ISO 11466:1997-06 (replaced by: DIN EN 16174:2012-11)

ISO (2007) Water quality-determination of selected elements by inductively coupled plasma optical emission spectrometry (ICPOES). DIN EN ISO 11885:2009-09. https://doi.org/10.31030 $/ 1530145$

ISO (2009) Water quality — determination of dissolved anions by liquid chromatography of ions. Part 1: determination of bromide, chloride, fluoride, nitrate, nitrite, phosphate and sulfate. DIN EN ISO 10304-1:2009-2107. https://doi.org/10.31030/1518948

Juncosa R, Delgado J, Cereijo JL, Muñoz A (2019) Hydrochemical evolution of the filling of the mining lake of As Pontes (Spain). Mine Water Environ 38(3):556-565. https://doi.org/10.1007/ s10230-019-00612-6 
Junge FW, Schultze M (2016) Open cast mines as river sediment and pollutant sinks - the example Mulde Reservoir (East Germany). In: Drebenstedt C, Paul M (eds) Proceedings of IMWA Conf, Leipzig, pp 159-166

Kirby CS, Cravotta CA (2005) Net alkalinity and net acidity 1: theoretical considerations. Appl Geochem 20(10):1920-1940. https://doi. org/10.1016/j.apgeochem.2005.07.002

Klapper H, Geller W (2001) Water quality management of mining lakes - a new field of applied hydrobiology. Acta Hydrochim Hydrobiol 29(6-7):363-374. https://doi.org/10.1002/1521401X(200112)29:6/7\%3c363:AID-AHEH363\%3e3.0.CO;2-E

Knöller K, Fauville A, Mayer B, Strauch G, Friese K, Veizer J (2004) Sulfur cycling in an acid mining lake and its vicinity in Lusatia, Germany. Chem Geol 204(3):303-323. https://doi.org/10.1016/j. chemgeo.2003.11.009

Koschorreck M, Tittel J (2007) Natural alkalinity generation in neutral lakes affected by acid mine drainage. J Environ Qual 36(4):11631171. https://doi.org/10.2134/jeq2006.0354

Koschorreck M, Boehrer B, Friese K, Geller W, Schultze M, WendtPotthoff K (2011) Oxygen depletion induced by adding whey to an enclosure in an acidic mine pit lake. Ecol Eng 37(12):1983-1989. https://doi.org/10.1016/j.ecoleng.2011.08.003

Koschorreck M, Wendt-Potthoff K, Bozau E, Herzsprung P, Geller W, Schultze M (2007) In-situ neutralization of pit lakes: processes in the sediment and limiting factors. In: Cidu R, Frau F (eds) Proceedings of IMWA Symposium, Cagliari, pp 215-219

Lee G, Bigham JM, Faure G (2002) Removal of trace metals by coprecipitation with $\mathrm{Fe}, \mathrm{Al}$ and $\mathrm{Mn}$ from natural waters contaminated with acid mine drainage in the Ducktown Mining District, Tennessee. Appl Geochem 17(5):569-581. https://doi.org/10.1016/ S0883-2927(01)00125-1

Lewis NM, Wangerud KW, Park BT, Fundingsland SD, Jonas JP (2003) Status of in situ treatment of Anchor Hill Pit Lake, Gilt Edge Mine Superfund Site, South Dakota, USA. In: Proceedings of 6th ICARD, Cairns, pp 779-788

Lund MA, Blanchette ML, Gonzalez-Pinto J, Green R, Mather C, Kleiber C, Lee S (2017) Are microcosms tiny pit lakes? In: Wolkersdorfer C, Sartz L, Sillanpää M, Häkkinen A (eds) Proceedings of 13th IMWA Congress, Lappeenrantha, pp 1204-1211

Mayes WM, Gozzard E, Potter HA, Jarvis AP (2008) Quantifying the importance of diffuse minewater pollution in a historically heavily coal mined catchment. Environ Pollut 151(1):165-175. https://doi. org/10.1016/j.envpol.2007.02.008

McCullough CD, Lund MA, May JM (2008) Field scale trials treating acidity in coal pit lakes using sewage and green waste. In: Rapantova N, Hrkal Z (eds) Proceedings of 10th IMWA Congress, Karlovy Vary, pp 599-602

Mitsch WJ, Nedrich SM, Harter SK, Anderson C, Nahlik AM, Bernal B (2014) Sedimentation in created freshwater riverine wetlands: 15 years of succession and contrast of methods. Ecol Eng 72:25-34. https://doi.org/10.1016/j.ecoleng.2014.09.116

Nixdorf B, Ramm J (2016) Overview of the ecological situation of selected lignite pit lakes in Germany [Übersicht zur ökologischen Situation ausgewählter Tagebauseen des Braunkohlebergbaus in Deutschland]. German Federal Environment Agency (ed), UBA TEXTE $68 / 2016$

Nixdorf B, Fyson A, Krumbeck H (2001) Review: plant life in extremely acidic waters. Environ Exp Bot 46(3):203-211. https ://doi.org/10.1016/S0098-8472(01)00104-6

Oldham C, Beer J, Blodau C, Fleckenstein J, Jones L, Neumann C, Peiffer S (2019) Controls on iron(II) fluxes into waterways impacted by acid mine drainage: a Damköhler analysis of groundwater seepage and iron kinetics. Water Res 153(1):11-20. https://doi. org/10.1016/j.watres.2018.12.024

Opitz J, Alte M, Bauer M, Schäfer W, Söll T (2017) Investigation of a pit lake acting as a large-scale natural treatment system for diffuse acid mine drainage. In: Wolkersdorfer C, Sartz L, Sillanpää M, Häkkinen A (eds) Proceedings of 13th IMWA Congress, Lappeenrantha, pp 1095-1102

Peiffer S (2016) Reaction time scales for sulphate reduction in sediments of acidic pit lakes and its relation to in-lake acidity neutralisation. Appl Geochem 73:8-12. https://doi.org/10.1016/j.apgeo chem.2016.07.009

Peine A (1998) Acidic lignite pit lakes - characterisation and quantification of biogeochemical processes and estimation of the importance of internal neutralisation [Saure Restseen des Braunkohletagebaus-Charakterisierung und Quantifizierung biogeochemischer Prozesse und Abschätzung ihrer Bedeutung für die seeinterne Neutralisierung]. Bayreuther Forum Ökologie, vol 62

Peine A, Tritschler A, Küsel K, Peiffer S (2000) Electron flow in an iron-rich acidic sediment-evidence for an acidity-driven iron cycle. Limnol Oceanogr 45(5):1077-1087. https://doi. org/10.4319/1o.2000.45.5.1077

Rönicke H, Schultze M, Neumann V, Nitsche C, Tittel J (2010) Changes of the plankton community composition during chemical neutralisation of the Bockwitz pit lake. Limnologica 40(2):191198. https://doi.org/10.1016/j.limno.2009.11.005

Salmon SU, Oldham CE, Ivey GN (2008) Assessing internal and external controls on lake water quality: limitations on organic carbondriven alkalinity generation in acidic pit lakes. Water Resour Res. https://doi.org/10.1029/2007WR005959

Schäfer W, Alte M, Bauer M, Söll T, Peiffer S (2016) Quantification of Acidity Deposition in the Sediment of a former lignite mining lake in the Wackersdorf Mining District (eastern Bavaria). In: Drebenstedt C, Paul M (eds) Proceedings of IMWA Conf, Leipzig, pp 236-243

Schultze M, Boehrer B, Duffek A, Herzsprung P, Geller W (2005) Introduction of river water as a tool to manage water quality in pit lakes. In: Loredo J, Pendás F (eds) Proceedings of 9th IMWA Congress, Oviedo, pp 273-279

Schultze M, Geller W, Wendt-Potthoff K, Benthaus FC (2009) Management of water quality in German pit lakes. In: Proceedings of 8th ICARD, Skellefteå, pp 273-279

Schultze M, Pokrandt KH, Hille W (2010) Pit lakes of the central German lignite mining district: creation, morphometry and water quality aspects. Limnologica 40(2):148-155. https://doi. org/10.1016/j.limno.2009.11.006

Skousen J, Zipper CE, Rose A, Ziemkiewicz P, Nairn R, McDonald LM, Kleinmann RL (2017) Review of passive systems for acid mine drainage treatment. Mine Water Environ 36(1):133-153. https://doi.org/10.1007/s10230-016-0417-1

StMUV (Bavarian State Ministry of the Environment and Consumer Protection) (2011) Bavarian Nature Conservation Act (BayNatSchG). Bavarian Law and Official Gazette GVB1: 82, BayRS 791-1-U

Totsche O, Pöthig R, Uhlmann W, Büttcher H, Steinberg CE (2003) Buffering mechanisms in acidic mining lakes-a model-based analysis. Aquat Geochem 9(4):343-359. https://doi.org/10.1023/ B:AQUA.0000029035.88090.eb

Tuttle LH, Dugan PR, Randles CI (1969) Microbial sulfate reduction and its potential utility as an acid mine water pollution abatement procedure. Appl Microbiol 17(2):297-302

Wendt-Potthoff K, Koschorreck M, Diez Ercilla M, Sánchez España J (2012) Microbial activity and biogeochemical cycling in a 
nutrient-rich meromictic acid pit lake. Limnologica 42(3):175188. https://doi.org/10.1016/j.limno.2011.10.004

Xu M, Dong X, Yang X, Chen X, Thang Q, Liu Q, Wang R, Yao M, Davidson TA, Jeppesen E (2017) Recent sedimentation rates of shallow lakes in the middle and lower reaches of the Yangtze River: patterns, controlling factors and implications for lake management. Water. https://doi.org/10.3390/w9080617
Zänker H, Richter W, Hüttig G (2003) Scavenging and immobilization of trace contaminants by colloids in the waters of abandoned ore mines. Colloid Surface A 217(1-3):21-31. https://doi. org/10.1016/S0927-7757(02)00555-1 